\title{
Colonic adenocarcinoma presenting as monocular metamorphopsia
}

\author{
Kirk A J Stephenson 지, ${ }^{1}$ Brian O'Tuama, ${ }^{1}$ Ian Dooley, ${ }^{1}$ Paul Connell ${ }^{1,2}$
}

${ }^{1}$ Ophthalmology, Mater Misericordiae University Hospital, Dublin, Ireland ${ }^{2}$ Medical Oncology, Mater Misericordiae University Hospital, Dublin, Ireland

\section{Correspondence to} Dr Kirk A J Stephenson; kirkstephenson@hotmail.com

Accepted 2 December 2021
Check for updates

(c) BMJ Publishing Group Limited 2022. No commercial re-use. See rights and permissions. Published by BMJ.

To cite: Stephenson KAJ, O'Tuama B, Dooley I, et al. BMJ Case Rep

2022;15:e245828.

doi:10.1136/bcr-2021-

245828

\section{DESCRIPTION}

A 53-year-old man presented with a 4-day history of right eye metamorphopsia. He had no other symptoms, specifically eye pain, headache or constitutional symptoms. He had no history of hypertension, diabetes or smoking. On direct questioning, he had recent mild fatigue, right upper quadrant pain, anorexia and partly voluntary weight loss. There was no change in bowel habit or melaena.

On examination, best corrected visual acuity was $6 / 12$ and $6 / 6$ in right and left eyes, respectively. He had no relative afferent pupil defect. Anterior segments were unremarkable, and intraocular pressures were $14 \mathrm{~mm} \mathrm{Hg}$. In the right eye, there were two discrete pale yellow choroidal masses in the temporal macula (figure 1A) associated with a localised exudative retinal detachment (ERD) affecting the fovea centralis (figure 1B). Autofluorescence imaging showed mottled hyperautofluorescence of the lesions and delineated extent of the ERD (figure 1C); fluorescein angiography showed late frame mottled hyperfluorescence of the choroidal lesions (figure 1D). The multiple choroidal lesions suggested choroidal metastasis over primary choroidal melanoma. Systemic workup for a primary malignancy showed deranged liver enzymes ( $\gamma$-glutamyltransferase $832 \mathrm{U} / \mathrm{L}$, alkaline phosphatase $269 \mathrm{IU} / \mathrm{L}$ ). CT scan of thorax/abdomen/pelvis showed widespread metastatic deposits to abdominal/thoracic lymph nodes, lung/pleura and liver with a likely primary non-obstructing mass in the posterior caecum (figure 2). There were no brain metastases. Due to liver dysfunction and overwhelming cancer load, he had sequelae of disseminated intravascular coagulation and venous thromboembolic (VTE) disease (eg, cerebral venous sinus thrombosis, sectoral pulmonary emboli). Carcinoembryonic antigen was extremely elevated at $>10000 \mu \mathrm{g} / \mathrm{L}$ (normal $<5 \mu \mathrm{g} / \mathrm{L}$ ) supporting a colorectal primary. An ultrasound-guided biopsy of a liver metastasis confirmed high grade metastatic colonic adenocarcinoma. With the guarded prognosis associated with advanced disease (stage 4) at presentation, palliative chemotherapy, orbital radiotherapy and systemic anticoagulation for VTE were commenced.

Colorectal adenocarcinoma is the third most common malignancy after breast/prostate, and lung, accounting for $10.6 \%$ of male cancer incidence and $<10 \%$ of all cancer deaths. ${ }^{12}$ Visual loss from metastatic disease can be caused by direct involvement of the eye/uvea, compressive optic neuropathy,

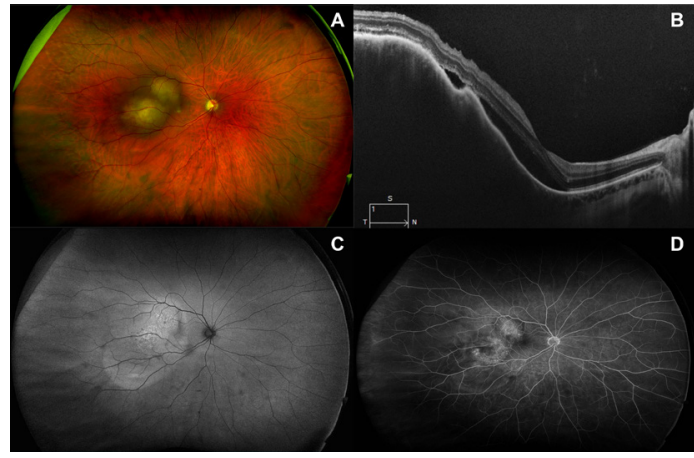

Figure 1 (A) Widefield colour fundus photograph (Optos California, Optos, UK) of the right eye demonstrating two pale/yellow lesions at the level of the choroid at the temporal macula. (B) Spectral domain optical coherence tomography (SD-OCT, Cirrus 5000, Carl Zeiss Meditec, USA) image through the fovea and superior choroidal lesion quantifying the elevation of the choroidal lesions and subretinal fluid/ exudative retinal detachment (ERD). (C) Widefield fundus autofluorescence (Optos California, Optos) with mottled hyperautofluorescence over the choroidal lesions and clear demarcation of the extent of ERD. (D) Late phase fluorescein angiogram (Optos California, Optos) demonstrating late mottled hyperfluorescence of the choroidal lesions.

visual pathway disease (ie, brain metastases) or paraneoplastic syndromes. ${ }^{3}$ Uveal metastases are reported in $0.5 \%-12 \%$ of advanced cancer cases, present at mean 58 years, are typically secondary to breast or lung primaries (colorectal origin reported in only 4\%) and suggest advanced stage cancer (ie,

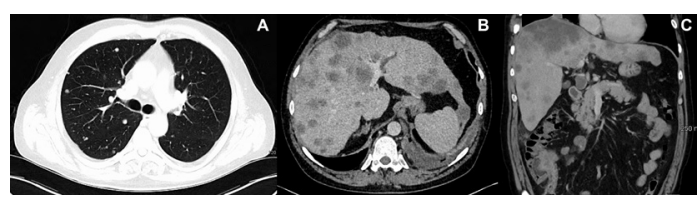

Figure 2 (A) Axial contrast CT scan of the chest showing multiple enhancing 'cannonball' metastatic deposits throughout bilateral lung parenchyma and filling defects of small pulmonary arterioles consistent with pulmonary emboli. (B) Axial non-contrast CT scan of the upper abdomen showing multiple hypodense lesions within both lobes of the liver representing metastatic deposits, one of which was subsequently biopsied to achieve a tissue diagnosis. There are also enlarged para-aortic retroperitoneal lymph nodes. (C) Coronal postcontrast CT scan of the lower thorax and abdomen showing the likely primary caecal tumour and disseminated metastases, most prominently in the liver. 


\section{Learning points}

- Uveal metastases are predominantly choroidal (88\%), present at mean 58 years, and suggest advanced stage cancer conferring a grim prognosis for survival (median 13 months).

- Most uveal metastases are secondary to breast or lung cancer; ancillary radiological and serological (eg, tumour markers) investigations can detect a primary tumour in up to $84 \%$ (previously known or occult).

- Local radiotherapy is an effective option for visually symptomatic tumours with $81 \%$ stabilising or improving.

TNM stage 4). ${ }^{34}$ Five-year survival for colorectal adenocarcinoma is $88 \%$ for stage 1 disease and $12.6 \%$ for stage 4 disease. $^{2}$ Uveal metastases may be multiple (29\%), are predominantly choroidal (88\%) and unilateral (76\%), and are the presenting feature of malignancy in $32 \%$, with primary tumour detection in $<50 \%$ of these. ${ }^{45}$ Choroidal metastases are typically yellow, have associated ERD and are usually mid-peripheral (80\%) rather than macular (12\%). ${ }^{4}$ Considering the poor systemic prognosis, local treatment aims to maintain/restore visual function with orbital radiotherapy being an effective option enabling improvement/resolution in $81 \%{ }^{6}$ with adverse effects (eg, retinal ischaemia, optic neuropathy) rarely manifesting during remaining life expectancy (median 13 months). ${ }^{6}$

Twitter Kirk A J Stephenson @karkstaphonsen
Acknowledgements The photographic, radiology, and oncology departments of the Mater Misericordiae University Hospital, Dublin, Ireland.

Contributors KAJS, BOT, ID, PPC: patient care, manuscript drafting and revision

Funding The authors have not declared a specific grant for this research from any funding agency in the public, commercial or not-for-profit sectors.

Competing interests None declared.

Patient consent for publication Consent obtained directly from patient(s).

Provenance and peer review Not commissioned; externally peer reviewed.

Case reports provide a valuable learning resource for the scientific community and can indicate areas of interest for future research. They should not be used in isolation to guide treatment choices or public health policy.

\section{ORCID iD}

Kirk A J Stephenson http://orcid.org/0000-0002-7462-7725

\section{REFERENCES}

1 Sung H, Ferlay J, Siegel RL, et al. Global cancer statistics 2020: GLOBOCAN estimates of incidence and mortality worldwide for 36 cancers in 185 countries. CA Cancer J Clin 2021:71:209-49.

2 Cronin KA, Lake AJ, Scott S, et al. Annual report to the nation on the status of cancer, part I: National cancer statistics. Cancer 2018:124:2785-800.

3 Saita L, Polastri D, De Conno F. Visual disturbances in advanced cancer patients: clinical observations. J Pain Symptom Manage 1999;17:224-6.

4 Shields CL, Shields JA, Gross NE, et al. Survey of 520 eyes with uveal metastases. Ophthalmology 1997;104:1265-76.

5 Shields JA, Shields $\mathrm{CL}$, Kiratli $\mathrm{H}$, et al. Metastatic tumors to the iris in 40 patients. Am J Ophthalmol 1995;119:422-30.

6 Minatel E, Trovò MG, Forner L, et al. The efficacy of radiotherapy in the treatment of intraocular metastases. Br J Radiol 1993;66:699-702.

Copyright 2021 BMJ Publishing Group. All rights reserved. For permission to reuse any of this content visit https://www.bmj.com/company/products-services/rights-and-licensing/permissions/

BMJ Case Report Fellows may re-use this article for personal use and teaching without any further permission.

Become a Fellow of BMJ Case Reports today and you can:

- Submit as many cases as you like

- Enjoy fast sympathetic peer review and rapid publication of accepted articles

- Access all the published articles

- Re-use any of the published material for personal use and teaching without further permission

Customer Service

If you have any further queries about your subscription, please contact our customer services team on +44 (0) 2071111105 or via email at support@bmj.com.

Visit casereports.bmj.com for more articles like this and to become a Fellow 